\title{
Triatoma sordida Stål 1859 (Hemiptera, Reduviidae: Triatominae) in Palms of Northeastern Argentina
}

\author{
María Esther Bar ${ }^{+}$, Cristina Wisnivesky-Colli*
}

\begin{abstract}
Cátedra de Artrópodos, Departamento de Biología, Facultad de Ciencias Exactas y Naturales y Agrimensura, Universidad Nacional del Nordeste, Avenida Libertad 5600, 3400 Corrientes, Argentina *Unidad de Ecología de Reservorios y Vectores de Parásitos, Departamento de Ciencias Biológicas, Facultad de Ciencias Exactas y

Naturales, Universidad de Buenos Aires, Buenos Aires, Argentina
\end{abstract}

Several palms species provide an important habitat for triatomines and associate vertebrates in tropical America. The objective of this work is to identify the triatomine species living in the palms of rural areas in the Province of Corrientes, and to estimate the potential epidemiological risk they represent for the residents of nearby houses.

The survey was carried out in a palm community in Colonia Laurel, Department San Roque, Province of Corrientes, Argentina. Samplings were performed in October, November and December 1998; January, February and March 1999; May and June 1999. Thirty palms: 27 (90\%) Butia yatay (Mart.) Becc. and 3 Acrocomia aculeata (Jacq.) Lodd ex Mart. were dissected. Triatoma sordida Stål 1859 was found in $96.2 \%$ of B. yatay and in all the A. aculeata palms. A total of 272 live T. sordida was collected; 36 of them (13.2\%) were found in bird nests in the frond and the remainder in other locations of the tree. The mean number of triatomines per palm was 9.6 (range 1-60, mode 2). T. sordida was collected during all the sampling months and all stages were present at all seasons. The highest population density was reached in spring and the lowest in autumn. Trypanosoma cruzi was detected in $38.5 \%$ in feces of 174 examined insects and identified as such, both by microscopical examination and PCR.

This is the first finding of $\mathrm{T}$. sordida populations in B. yatay, an endemic palm of South America distributed in southern Brazil, Uruguay and northeastern Argentina. The high infection prevalence found in this work suggests that $\mathrm{T}$. sordida plays an essential role in the maintenance of the wild $\mathrm{T}$. cruzi transmission cycle in northeastern Argentina.

Key words: Triatoma sordida - palms - wild triatomines - Butia yatay - Argentina

In America, palm trees have been found infested with different species of triatomines. The most frequently cited are Rhodnius prolixus, $R$. neglectus, $R$. pictipes, $R$. nasutus, $R$. pallescens, $R$. neivai, $R$. robustus, Triatoma maculata, T. pseudomaculata, T. dimidiata, T. sordida, Panstrongylus megistus, $P$. lignarus, Eratyrus mucronatus and $E$. cuspidatus (Barretto et al. 1969, Forattini et al. 1971, Gamboa 1973, Feliciangeli \& Torrealba 1977, Whitlaw \& Chaniotis 1978, D' Alessandro et al. 1984, Rossell-Reyes 1984, Diotaiuti et al. 1993).

Regarding their epidemiological role, some species like $R$. prolixus and P. megistus are more important vectors of $T$. cruzi than others like $R$. robustus, $R$. neglectus and $R$. pictipes. Palms could

\footnotetext{
${ }^{+}$Corresponding author. Fax: +54-3783-473930. E-mail: mebar@exa.unne.edu.ar Received 20 September 2000

Accepted 20 June 2001
}

also represent dispersion foci of triatomines to human dwellings and peridomestic premises such as chicken houses.

In Argentina there are few records about the presence of $T$. sordida in palm trees (Carcavallo et al. 1988) but neither longitudinal nor systematic studies have ever been performed on triatomine populations colonizing palms.

The aims of this work were to identify the triatomine species living in the palms of rural areas in the Province of Corrientes, as well as to estimate the potential epidemiological hazard that these $T$. cruzi vectors represent for the residents of nearby houses.

\section{MATERIALS AND METHODS}

Study area - The survey was carried out in a palm community (Figure) located in Colonia Laurel, Department San Roque, Province of Corrientes, Argentina $\left(29^{\circ} \mathrm{S}, 58^{\circ} \mathrm{W}\right)$. The area is included in the Humid Eastern District of the Chaqueña Phytogeographic Province. The climate is humid, mesothermal, maximum precipitations occur in March and 


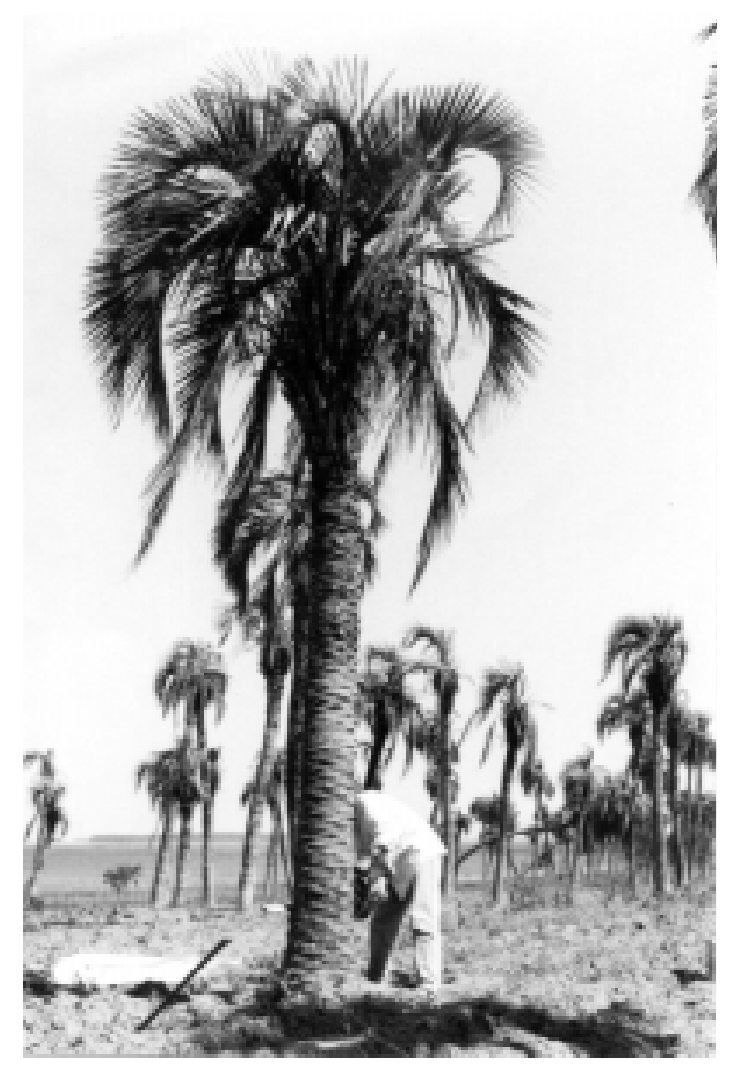

General view of the palm community. First plane: Butia yatay Colonia Laurel, Department San Roque, Province of Corrientes, Argentina, 1998-1999

November, while minimum values are registered in June and August (Duarte 1978/80). This area was selected by its typical sylvatic palms and the presence of nearby houses with permanent inhabitants.

Sampling design - Samplings were carried out in October, November and December 1998 (spring); January, February and March 1999 (summer); May and June 1999 (autumn). In each sampling, four parallel transects of $300 \mathrm{~m}$ in length were placed, 50 $\mathrm{m}$ apart from each other, leaving approximately 25 $\mathrm{m}$ between the palms and the nearby heterogeneous environments to avoid the border effect. A minimum of four palms per month (one per transect) was selected at random to be dissected.

Palm determination and dissection - Palm species were taxonomically determined using appropriate keys (Henderson et al. 1995). After cutting the palm at the base, it was put on a white cloth to facilitate the detection of escaping insects. Parts sprayed with tetramethrin $0.2 \%$ to dislodge bugs, and carefully examined were as follows: the stipe, the axis of the frond bases, the petioles (including the broad ones of fallen dead leaves), the inner spathe of the inflorescence and the fibrous tissue that remains after sheath disintegration. The capture effort was estimated using the time spent by one person to inspect a palm (man/hour). Site data recorded included: palm height and diameter, distance to the nearest dwelling, and the location, if present, of bird nests, vertebrate, and their feces.

Triatomine collection - Palms were considered as infected when any sign of triatomine presence was found, such as dead or live nymphs and adults, eggs and exuviae. Collected triatomines were put in properly labeled plastic jars with pleated filter paper and shipped immediately to our laboratory in Corrientes.

Laboratory studies - The taxonomic determination of triatomines was done using appropriate keys (Lent \& Wygodzinsky 1979, Brewer et al. 1983). Insects were grouped according to their developmental stage and sex and their number was recorded.

The feces of triatomines, obtained by abdominal pressure, were diluted $1: 1$ in $0.85 \%$ sodium chloride solution and examined microscopically at 400x for $T$. cruzi detection. T. cruzi identification was performed by morphological criteria (Barretto 1965) and the PCR technique. T. cruzi DNA was searched from dry triatomine feces collected in Whatman no. 1 paper by using the specific TCZ and Morel primers (Russomando et al. 1996).

\section{RESULTS}

Among the 30 palms that were dissected, 27 (90\%) were identified as Butia yatay (Mart.) Becc. and $3(10 \%)$ as Acrocomia aculeata (Jacq.) Lodd ex Mart., both belonging to the Subfamily Arecoidae. The mean length of palms was $5.82 \mathrm{~m}$ and the mean stipe diameter was $34 \mathrm{~cm}$. The mean distance of palms to the nearest dwelling was 190.7 $\mathrm{m}$, ranging from 1,000 to $50 \mathrm{~m}$. The mean time of dissection per palm was $2 \mathrm{~h}$ (range: $0.55-3 \mathrm{~h}$ ) and the total capture effort was $8 \mathrm{~m} / \mathrm{h}$ per palm.

Bird nests were present in 26.7\% (8/30) palms and half of them (4/8) belonged to the Furnariidae family.

Evidences of the presence of mammals were recorded in 20\% (6/30) palms. Those were: opossum individuals (Didelphis albiventris), their nests and feces and/or rodent scats.

The following triatomine species were identified in B. yatay: T. sordida, T. platensis Neiva 1913 and Psammolestes coreodes Bergroth 1911. T. sordida was the only species found in A. aculeata.

In one bird nest built on a $B$. yatay palm we found $16 T$. sordida, 2 first stage nymphs of $T$. platensis and 4 fifth stage nymphs of $P$. coreodes.

T. sordida was found in $96.2 \%$ B. yatay and in all the dissected A. aculeata. 
Table I shows the density and the infestation indexes of triatomines in palms, as well as relative abundance of nymphs and adults, along the seasons.

Most of the palms (80\%) were exclusively infested by T. sordida nymphs, followed by $13.3 \%$ palms with nymphs and adults and one palm harboring only adults.

The whole $T$. sordida population collected was 272 live specimens; 36 of them (13.2\%) were found in bird nests located in the palm frond, and the remainder in the axis of the frond and other hiding places spread over the tree. The number of triatomines per palm ranged between 1 and 60 individuals (mean 9.6; mode 2).

$T$. cruzi infection - Sixty-seven T. sordida out of $174(38.5 \%)$ examined insects showed trypanosomes in feces. Their identity as T. cruzi was subsequently confirmed by PCR. Infection rate increased linearly with age (regression line: $\mathrm{y}=13,8 \mathrm{x}-$ $25,4, \mathrm{R}^{2}=0.9894$ ) (Table II). Detailed results on $T$. cruzi infection detected by PCR will be published separately.

\section{TABLE I}

Seasonal infestation index, density index and relative abundance of Triatoma sordida, T. platensis and

Psammolestes coreodes in palms, 1998-1999, Colonia Laurel, Department San Roque, Province of Corrientes, Argentina

\begin{tabular}{lrcrc}
\hline Variables & Spring & Summer & Fall & Total \\
\hline No. of dissected palms & 13 & 11 & 6 & 30 \\
$\begin{array}{l}\text { No. of infested palms } \\
\text { Infestation Index }\end{array}$ & 13 & 10 & 6 & 20 \\
$\begin{array}{l}\text { Density Index } \\
\text { Total no. of nymphs }\end{array}$ & 100 & 90 & 100 & 96.7 \\
$\quad \begin{array}{l}\text { and eggs collected } \\
\text { Total no. of adults }\end{array}$ & $151^{c}$ & $67^{c, d}$ & 54 & 272 \\
collected & 6 & 0 & 0 & 6.6 \\
\hline
\end{tabular}

$a$ : no. of positive palms/no. of examined palms; $b$ : no. of collected triatomines/no. of positive palms; $c$ : one $T$. sordida egg; $d$ : two first stage nymphs of $T$. platensis and 4 fifth stage nymphs of $P$. coreodes

\section{DISCUSSION}

This work represents the first longitudinal study published in Argentina about triatomine infestation in palms.

T. sordida was the dominant species collected in $B$. yatay compared with $T$. platensis and $P$. coreodes. This result constitutes the first finding of $T$. sordida in the mentioned palm species, which is endemic of South America and has exclusively been cited for Argentina, Uruguay and State of Rio Grande do Sul in Brazil (Henderson et al. 1995).
TABLE II

Trypanosoma cruzi infection in Triatoma sordida developmental stages, Colonia Laurel, Department San Roque, Province of Corrientes, Argentina

\begin{tabular}{lccc}
\hline Stage & $\begin{array}{c}\text { No. } \\
\text { collected }\end{array}$ & $\begin{array}{c}\text { No. (\%) } \\
\text { examined }\end{array}$ & $\begin{array}{c}\text { No. (\%) } \\
\text { infected }\end{array}$ \\
\hline N1 & 23 & $4(17)$ & $0(0)$ \\
N2 & 48 & $22(46)$ & $4(18)$ \\
N3 & 72 & $44(61)$ & $13(30)$ \\
N4 & 74 & $61(82)$ & $28(46)$ \\
N5 & 48 & $40(83)$ & $22(55)$ \\
Adults & 6 & 3 & $0(0)$ \\
\hline Total & 271 & $174(64)$ & $67(38.5)$ \\
\hline
\end{tabular}

The high infestation indexes we found in $B$. yatay are similar to those reported for other ensembles of palms and triatomines. Thus, $R$. neglectus and $R$. prolixus were collected in 95 and 92\% of examined Orbignya martiana, respectively (Bento et al. 1984, D’ Alessandro et al. 1984).

On the other hand, the presence of different triatomine species in one single palm is a common fact and usually one of them is dominant due to its frequency and relative abundance. Tonn et al. (1976) confirmed that $75.1 \%$ Acrocomia $\mathrm{sp}$. was infected by five triatomine species of the following genus: Eratyrus, Panstrongylus, Rhodnius, and Triatoma. Feliciangeli and Torrealba (1977) cited $R$. prolixus as the most abundant in Copernicia tectorum, coexisting with T. maculata in $3.8 \%$ palms. Whitlaw and Chanotis (1978) reported the simultaneous presence of $R$. pallescens and T. dimidiata, in $91 \%$ of Scheelea zonensis palms, although the first species was clearly dominant.

In the present work, all dissected A. aculeata were exclusively colonized by $T$. sordida. In Brazil, the synonyms species $A$. sclerocarpa was mostly infested by $R$. neglectus and secondarily by $T$. sordida and P. megistus (Barretto et al. 1969, Diotaiuti \& Dias 1984).

In Uberaba, State of Minas Gerais, Barretto et al. (1969) dissected 232 palms of six different species and collected 949 specimens of $T$. sordida. Infestations recorded (from 17.6 to 50\%) were lower than those found in our work. In addition to the mean number of insects per palm, which ranged between 2.1 and 8.3 triatomines, was similar to the densities found in B. yatay.

Besides, the only habitat recorded for $R$. brethesi was Leopoldinia piassava in the Rio Negro, region of Barcelos, Amazonas (Mascarenhas 1991). This author collected in Urumutum a mean number of 5.04 insects per palm and 1.1 in Rilau, these den- 
sities were lower than the registered in the present investigation.

We collected $T$. sordida in all sampled months. The highest population density was reached in spring and the lowest in autumn. The adult presence might have been underestimated since males and females fly to colonize new biotopes. It is worth of mentioning that all instar nymphs were present during the three sampling seasons, suggesting that younger stages endure winter conditions, a situation which has not been observed for other wild triatomine species in Northern Argentina (Wisnivesky-Colli 1994).

Our results indicate that palms represent an advantageous habitat for $T$. sordida because they provide refuge to potential feeding sources such as birds, amphibians, bats, opossums, rodents and reptiles. Besides, adequate microclimatic conditions in those places where triatomines shelter might buffer the high summer temperatures, as it was shown for palms from Venezuela (Pifano 1973, Rossell-Reyes 1984).

The proportion of $T$. sordida infected by $T$. cruzi (38.5\%) was higher than rates obtained by Barretto et al. (1969) for T. sordida in three palm species (15.3\%), although he found a prevalence of $29.3 \%$ for those specimens collected from Orbignya martiana.

Among the few T. platensis and P. coreodes caught by us in bird nests, no T. cruzi infection was detected, possibly due to the fact that those insects had fed on bird.

Most of the infected triatomines were found in those palms where the presence of Didelphis albiventris and rodent feces was recorded. This result is in agreement with Barretto et al. (1969) and Monteiro et al. (1999) who consider opossums and rodents as $T$. cruzi reservoirs in palms.

The high infection prevalence found in this work suggests that $T$. sordida plays an essential role in the maintenance of the wild transmission cycle in northeastern Argentina. On the other hand, leaves, bark and fruits from palms are frequently used by rural inhabitants, giving rise to an important risk of transmission to humans. In particular, fronds and stipes are used in walls and roofs of houses, favoring the passive transport of wild triatomines to the domestic environment, as pointed out by Gamboa (1973) and Pifano (1973) for $R$. prolixus in Venezuela.

Further studies are needed to evaluate the actual risk that palm T. sordida populations represent for the inhabitants of nearby houses.

\section{ACKNOWLEDGMENTS}

To E Oscherov, M Damborsky, M Alvarez, G Avalos, H Presmann for their assistance on the field and laboratory work. To J Vargas for his valuable help and to S Pîetrokovsky for the English version of the manuscript.

\section{REFERENCES}

Barreto MP 1965. Tripanossomos semelhantes ao Trypanosoma cruzi em animais silvestres e sua identificaçao com o agente etiológico da doença de Chagas. Rev Inst Med Trop São Paulo 7: 304-315.

Barretto MP, Albuquerque RDR, Funayama GK 1969. Estudos sôbre reservatórios e vetores silvestres do "Trypanosoma cruzi". XXXVI: investigações sôbre triatomíneos de palmeiras no município de Uberaba, MG, Brasil. Rev Bras Biol 29: 577-588.

Bento DNC, Branco AZCL, Freitas MR, Pinto AS 1984. Epidemiologic studies of Chagas' disease in the urban zone of Teresina, State of Piauí, Northeastern Brasil. Rev Soc Bras Med Trop 17: 199-203.

Brewer M, Garay M, Gorla D, Murua F, Favot R 1983. Caracterización de los estadios ninfales del género Triatoma Laporte 1833. II. Triatoma platensis Neiva 1913, Triatoma delpontei Romaña y Ábalos 1947, Triatoma sordida Stål 1859. (Hemiptera, Reduviidae). Rev Soc Entomol Argent 42: 219-241.

Carcavallo RU, Canale DM, Martínez A 1988. Habitats de triatominos argentinos y zonas ecológicas donde prevalecen. Chagas 5: 8-17.

D'Alessandro A, Barreto P, Saravia N, Barreto M 1984. Epidemiology of Trypanosoma cruzi in the oriental plains of Colombia. Am J Trop Med Hyg 33: 10841095.

Diotaiuti L, Dias JCP 1984. Ocorrência e biologia do Rhodnius neglectus Lent 1954 em macaubeiras da periferia de Belo Horizonte, Minas Gerais. Mem Inst Oswaldo Cruz 79: 293-301.

Diotaiuti L, Loiola CF, Falcão PL, Dias JCP 1993. The ecology of Triatoma sordida in natural environments in two different regions of the State of Minas Gerais, Brazil. Rev Inst Med Trop São Paulo 35: 237-245.

Duarte LA 1978/80. Lineamientos para las Políticas de Desarrollo Urbano de la Provincia de Corrientes, Secretaría de Estado Desarrollo Urbano y Vivienda, Corrientes, Argentina.

Feliciangeli PD, Torrealba JW 1977. Observaciones sobre Rhodnius prolixus (Hemiptera, Reduviidae) en su biotopo silvestre Copernicia tectorum. Bol Dir Malariol Saneam Ambien 17: 198-205.

Forattini OP, Ferreira OA, da Rocha e Silva EO, Rabello EX, Santos JLF 1971. Aspectos ecológicos da tripanossomose Americana. II. Distribuição e dispersão local de triatomíneos em ecótopos naturais e artificiais. Rev Saúde Púb São Paulo 5: 163-191.

Gamboa JC 1973. La población silvestre de Rhodnius prolixus en Venezuela. Arch Venez Med Trop Parasit Med 5: 321-352.

Henderson A, Galeano G, Bernal R. 1995. Field Guide to the Palms of the Americas, Princeton University Press, New Jersey, 352 pp.

Lent H, Wygodzinsky P 1979. Revision of the Triatominae (Hemiptera, Reduviidae) and their significance as vectors of Chagas' disease. Bull Am Mus Nat History 163: 123-520. 
Mascarenhas B M, 1991. Triatomíneos da Amazônia: sobre o habitat e algumas considerações comportamentais de Rhodnius brethesi Matta, 1919 (Hemiptera: Reduviidae: Triatominae) na Região do Médio Rio Negro, Amazonas. Bol Mus Para Emilio Goeldi, sér Zool 7: 107-116.

Monteiro PS, Rebelo JMM, Costa JML, Nascimento RJ, Teixeira ARL 1999. Cadeia trófica e ciclo de transmissão do Trypanosoma cruzi em palmeiras Orbignya phalerata. Rev Soc Bras Med Trop 32 (Supl. II): 123.

Pifano FC 1973. La dinámica epidemiológica de la enfermedad de Chagas en el Valle de los Naranjos, Estado de Carabobo, Venezuela. I. Contribución al estudio de los focos naturales silvestres del Schizotripanum cruzi Chagas 1909. Arch Venez Med Trop Parasitol Med 5: 1-29.

Rossell-Reyes O 1984. A Comparison of the Feeding Performances of Rhodnius prolixus Stål and Rhodnius robustus Larrousse (Hemiptera: Triatominae), $\mathrm{PhD}$ Thesis, University of London, 339 pp.

Russomando G, Rojas de Arias A, Almirón M, Figueredo A, Ferreira ME, Morita K 1996. Trypanosoma cruzi: polymerase chain reaction-based detection in dried feces of Triatoma infestans. Exp Parasitol 83: 62-66.

Tonn RJ, Carcavallo RU, Ortega R, Carrasquero B 1976. Métodos de estudio de triatominos en el medio silvestre. Bol Dir Malariol Saneam Ambien 16: 146152.

Whitlaw JT, Chaniotis BN 1978. Palm trees and Chagas' disease in Panamá. Am J Trop Med Hyg 27: 873-881.

WHO-World Health Organization 1991. Control of Chagas Disease, WHO Technical Report Series 811, 95 pp.

Wisnivesky-Colli C 1994. Triatominos vectores secundarios del Trypanosoma cruzi, su domiciliación potencial, Thesis, Universidad de los Andes, Mérida, Venezuela, p. 83-92. 
